\title{
$\begin{array}{lllllllllllllllll}\mathbf{R} & \mathbf{O} & \mathbf{Z} & \mathbf{P} & \mathbf{R} & \mathbf{A} & \mathbf{W} & \mathbf{Y} & \text { I } & \text { A } & \mathbf{R} & \mathbf{T} & \mathbf{Y} & \mathbf{K} & \mathbf{U} & \mathbf{L} & \mathbf{Y}\end{array}$
}

Prawo Kanoniczne

63(2020) nr 3

DOI:10.21697/pk.2020.63.3.01

KS. ZBIGNIEW JANCZEWSKI

Wydział Prawa Kanonicznego

Uniwersytetu Kardynała Stefana Wyszyńskiego w Warszawie

ORCID: 0000-0002-7395-2526

\section{SPRAWOWANIE SAKRAMENTÓW \\ UZDROWIENIA W OKRESIE STANU \\ EPIDEMICZNEGO W ŚWIETLE PRAWA \\ KANONICZNEGO}

Treść: Wstęp. - 1. Pojęcia stanu epidemicznego i niebezpieczeństwa śmierci. - 2. Sprawowanie sakramentu pokuty i pojednania. - 3. Sakrament namaszczenia chorych. - Zakończenie.

\section{Wstęp}

Dzięki sakramentom wtajemniczenia chrześcijańskiego człowiek otrzymuje nowe życie w Chrystusie. Wciąż jednak egzystuje w przybytku doczesnego zamieszkania, którym jest ludzkie ciało. Stąd jest poddawany cierpieniu, chorobom oraz śmierci. Niestety to nowe życie może być utracone poprzez popełnianie grzechów. Jezus, lekarz dusz i ciał ludzkich, odpuszczający grzechy i uzdrawiający z różnych chorób ludzi, których spotykał podczas działalności na ziemi chce, żeby Kościół mocą Ducha św. kontynuował Jego dzieło uzdrawiania i zbawiania, obejmujące także ludzkie ciało. Jest to zasadniczy cel dwóch sakramentów uzdrowienia - pokuty i namaszczenia chorych. ${ }^{1}$

Sprawuje się je zazwyczaj w zwyczajnych okolicznościach, kiedy wierni mają nieograniczony wstęp do świątyń, a kapłani bez problemu mogą się dostać do szpitali, domów opieki, czy prywatnych mieszkań.

\footnotetext{
${ }^{1}$ Katechizm Kościoła Katolickiego, nr 1420-1421, Poznań 1994, s. 340.
} 
Raz na kilkanaście, lub kilkadziesiąt lat na świecie rozprzestrzenia się epidemia choroby zakaźnej, zbierająca śmiertelne żniwo. Tak też się stało z początkiem 2020 r., gdy pojawiła się niezwykle groźna choroba płuc, wywoływana przez koronawirus noszący nazwę SARS-CoV-2. Od dnia 14 marca tego roku został wprowadzony w Polsce stan zagrożenia epidemicznego. Najbardziej skuteczną metodą pomagającą zmniejszyć rozprzestrzenianie epidemii jest ograniczenie kontaktów międzyludzkich. Stanowi to jednak problem w przypadku sprawowania sakramentów, w tym również pokuty i namaszczenia chorych, dzięki którym osoby zarażone, a także żyjący w potencjalnym zagrożeniu zarażeniem otrzymują pojednanie z Bogiem i Kościołem oraz łaski duchowe, pomagające $\mathrm{w}$ walce $\mathrm{z}$ chorobą. Niniejsze opracowanie posługując się analizą odpowiednich norm prawa kanoniczego ma za zadanie odpowiedzieć na pytanie, w jaki sposób należy sprawować sakramenty uzdrowienia w trudnej sytuacji stanu epidemicznego.

\section{Pojęcia stanu epidemicznego i niebezpieczeństwa śmierci}

Epidemia w znaczeniu medycznym to występowanie w określonym czasie i na określonym terenie przypadków zachorowań lub innych zjawisk związanych ze zdrowiem, w liczbie większej niż oczekiwana. ${ }^{2}$ Istnieje również jej określenie prawne. Definicję legalną epidemii sformułowano w następujący sposób: „wystąpienie na danym obszarze zakażeń lub zachorowań na chorobę zakaźną w liczbie wyraźnie większej niż we wcześniejszym okresie albo wystąpienie zakażeń lub chorób zakaźnych dotychczas niewystępujących". ${ }^{3}$ Dnia 13 marca 2020 r minister zdrowia mocą rozporządzenia ogłosił na terenie kraju stan zagrożenia epidemicznego. Czytamy w nim: „W okresie od dnia 14 marca 2020 r. do odwołania na obszarze Rzeczypospolitej Polskiej ogłasza się stan zagrożenia epidemicznego w związku z zakażeniami wirusem SARS-CoV-2. Jeżeli zagrożenie epidemiczne lub epidemia występuje na obszarze więcej niż jednego województwa,

\footnotetext{
${ }^{2}$ M. Porta, A Dictionary of Epidemiology, Oxford 2008, s. 79.

${ }^{3}$ Ustawa z dnia 5 grudnia 2008 r. o zapobieganiu i zwalczaniu zakażeń i chorób zakaźnych i ludzi (Dz.U. z 2019 r. poz. 1239).
} 
stan zagrożenia epidemicznego lub stan epidemii ogłasza i odwołuje, $\mathrm{w}$ drodze rozporządzenia, minister zdrowia w porozumieniu $\mathrm{z}$ ministrem do spraw administracji publicznej, na wniosek Głównego Inspektora Sanitarnego". ${ }^{4}$

Epidemie łączą się często ze stosunkowo dużą ilością zgonów. Tak było również w wielu przypadkach zarażenia koronowirusem wywołującym zapalenie płuc. W całym świecie umierały tysiące zarażonych. W takiej sytuacji podczas każdej epidemii Kościół musi się zmierzyć z problemem możliwości bezpiecznego i skutecznego udzielania sakramentów, szczególnie uzdrowienia, a więc pokuty i namaszczenia chorych.

Prawo kanoniczne nie zna terminu „stan epidemiczny”, stosuje natomiast inny - „niebezpieczeństwo śmierci”. Czym więc ono jest? M. Pastuszko tak trafnie charakteryzuje ten termin kanoniczny: przez niebezpieczeństwo śmierci rozumie się stan, kiedy utrata życia ludzkiego jest prawdopodobna, ale nie jest równocześnie wykluczone przeżycie człowieka. Należy odróżnić niebezpieczeństwo śmierci od agonii, kiedy śmierć jest moralnie pewna i bliska. ${ }^{5}$ Zatem interesujący nas termin określa sytuację, w której człowiekowi zagraża śmierć na skutek jakichś zewnętrznych, groźnych czynników, chociaż nie zawsze muszą one doprowadzić go do utraty życia.

Trzeba w tym miejscu zapytać, czy w przypadku stanu epidemicznego można mówić o znajdowaniu się wiernego w niebezpieczeństwie śmierci? Odpowiedzi należy szukać w dokumentach Stolicy Apostolskiej z początku poprzedniego stulecia, kiedy w Europie toczyła się I wojna światowa. Wtedy to pojawiły się dekrety dotyczące absolucji generalnej, które były niejako pierwowzorem aktualnej normy kodeksowej, zezwalającej na takie rozwiązanie w niebezpieczeństwie śmierci. ${ }^{6}$ Dnia 6 lutego 1915 r. Penitencjaria Apostolska dekretem Proposito huic wydała zezwolenie na udzielanie zbiorowego

\footnotetext{
${ }^{4}$ Dz. U. z 2020 r. poz. 433.

${ }^{5}$ M. Pastuszko, Sakrament pokuty i pojednania, Kielce 1999, s. 113.

${ }^{6}$ KPK 1983, kan. 961 par. 1.
} 
rozgrzeszenia żołnierzom powołanym na front. ${ }^{7}$ Natomiast około trzy miesiące później, 25 maja zrównała żołnierzy powołanych na front z tymi, którzy zostali wcześniej zmobilizowani. ${ }^{8} \mathrm{~W}$ kolejnym dokumencie z 29 maja 1915 r. Penitencjaria Apostolska wyjaśniła, że żołnierz zmobilizowany w czasie wojny może być przyrównany do osoby znajdującej się w niebezpieczeństwie śmierci. ${ }^{9}$

Problem zagrożenia utraty życia pojawił się ponownie podczas II wojny światowej. Stąd też papież Pius XII wydając Adhortację apostolską Asperis commoti w dniu 8 grudnia 1939 r. rozszerzył możliwość udzielania rozgrzeszenia zbiorowego bez uprzedniej spowiedzi indywidualnej na ludność cywilną zagrożoną niebezpieczeństwem śmierci z powodu bombardowań i ostrzału artyleryjskiego. ${ }^{10}$ Ponieważ postanowienie powyższe wywołało dyskusje, czy takowa absolucja dotyczy jedynie sytuacji trwającego już nalotu lub ostrzału, czy też wcześniejszego przewidywania takowych, Penitencjaria Apostolska wyjaśniła w dniu 10 grudnia 1940 r., że chodzi tutaj nawet o okres wcześniejszy, kiedy można się ataku spodziewać. ${ }^{11}$

Cytowane powyżej dokumenty zezwalały na zastosowanie nadzwyczajnej formy spowiedzi w odniesieniu do żołnierzy i cywilów, którzy znaleźli się w sytuacji, w której możliwa była utrata przez nich życia na skutek udania się w przyszłości na front i ewentualnym udziale w walkach oraz na skutek możliwości znalezienia się na obszarze bombardowań czy ostrzału, które mogły (chociaż nie musiały) skutkować utratą życia. Jak wynika z powyższych dokumentów, niebezpieczeństwo śmierci nie musi grozić bezpośrednio, wystarcza, że pojawi się realne prawdopodobieństwo utraty życia.

W Motu proprio Misericordia Dei papieża Jana Pawła II z 7 kwietnia 2002 r. znajdujemy dodatkowe rozróżnienie interesującego nas terminu. Czytamy tu o przypadku „bliskiego niebezpieczeństwa

\footnotetext{
${ }^{7}$ Decretum, AAS 7(1915) s. 72.

${ }^{8}$ Decretum, AAS 7(1915) s. 281.

${ }^{9}$ Dubium, AAS 7(1915) s. 282.

${ }^{10}$ Adhortatio, AAS 31(1939) s. 696-701.

${ }^{11}$ Dubium, AAS 32(1940) s. 571.
} 
śmierci”. Wtedy, o ile jest to możliwe, należy wezwać wiernych do wzbudzenia przez każdego z nich aktu żalu, przed udzieleniem absolucji generalnej. ${ }^{12}$ Można z tego wnioskować, że „niebezpieczeństwo bliskie" może skutkować brakiem czasu na wzbudzenie aktu żalu za popełnione grzechy. Niekoniecznie musi być to stan agonii, lecz chwile przed nagłą utratą życia, na przykład tuż przed rozbiciem się samolotu. Zatem przy wystąpieniu „Zwyczajnego” niebezpieczeństwa śmierci ma się zazwyczaj do czynienia z wystarczającym czasem na wzbudzenie wspomnianego żalu.

Po przedstawieniu powyższych argumentów należy wrócić do wcześniej postanowionego pytania, czy w przypadku stanu epidemicznego można mówić o znajdowaniu się wiernego w niebezpieczeństwie śmierci? Co do tego nie ma wątpliwości. Epidemia choroby zakaźnej stwarza sytuację, w której prawie każdy człowiek może się taką chorobą zakazić, nawet stosując się do szczególnych zasad higieny. Natomiast fakt zarażenia naraża go na utratę życia. Znajduje się zatem w stanie kanonicznie rozumianego niebezpieczeństwa śmierci.

Jedna $\mathrm{z}$ naczelnych zasad stosowanych w prawie kanonicznym to: salus animarum suprema lex. Cel Kościoła, zbawienie człowieka wpływa na jego prawo, koordynując życie członków jego społeczności, ułatwia korzystanie z dóbr nadprzyrodzonych. ${ }^{13}$ Cytowaną zasadę stosuje się również w niektórych przypadkach zagrożenia ludzkiego życia, kiedy zezwala się na udzielanie sakramentów bez zachowania wszystkich wymogów przestrzeganych w zwyczajnych sytuacjach.

\section{Sprawowanie sakramentu pokuty i pojednania}

Sakrament pokuty i pojednania ma między innymi za zadanie odpuszczenie grzechów wiernego. Osoby prowadzące głębokie życie duchowe spowiadają się często, inni zazwyczaj przy okazji ważniejszych spotkań rodzinnych - jubileuszy, chrztów, ślubów, pogrzebów, itp. Część wiernych przystępuje do spowiedzi tylko przed Wielkanocą,

\footnotetext{
${ }^{12}$ List Apostolski w formie Motu proprio Misericordia Dei o niektórych aspektach sprawowania sakramentu pokuty, Poznań 2002, s. 15.

${ }^{13}$ R. SobańsKi, Kościół-prawo-zbawienie, Katowice 1979, s. 230.
} 
czy Bożym Narodzeniem. Sytuacja zmienia się kiedy człowiekowi zaczyna bezpośrednio zagrażać śmierć. Podczas wojny, groźnej epidemii, częściej szuka się sposobu pojednania z Bogiem i bliźnimi. Na przeciw wiernych wychodzi wtedy Kościół proponując inne formy sakramentu pokuty, niż praktykowana na co dzień w konfesjonale. Jedną z nich jest rozgrzeszenie wielu penitentów bez indywidualnego odpuszczenia grzechów.

Ustawodawca kościelny dopuszcza równoczesną absolucję wielu penitentów w dwóch przypadkach. Jeden z nich to zaistnienie poważnej konieczności, kiedy ze względu na liczbę penitentów nie ma dostatecznie wielu spowiedników do wysłuchania pojedynczych spowiedzi w odpowiednim czasie, na skutek czego penitenci bez własnej winy musieliby pozostawać bez łaski sakramentalnej, albo bez przyjęcia Komunii św. Dostateczną koniecznością nie jest duży napływ penitentów, który może się zdarzyć podczas uroczystości czy pielgrzymki. Ocena sytuacji należy do biskupa diecezjalnego, po uwzględnieniu kryteriów uzgodnionych z członkami konferencji biskupów. ${ }^{14}$ Czy norma ta ma swoje zastosowanie w przypadku epidemii? Trzeba bliżej przyjrzeć się przesłankom, po wystąpieniu których można udzielić absolucji generalnej.

W przypadku analizowanej normy przesłankami tymi są duża liczba penitentów pragnąca w tym samym czasie przystąpić do spowiedzi oraz brak wystarczającej ilości spowiedników, którzy by udzieli im sakramentu indywidualnie, pozostanie bez łaski sakramentu pokuty i Komunii św. Ustawodawca równocześnie wyklucza udzielenie rozgrzeszenia zbiorowego podczas dużego napływu penitentów na wielką uroczystość. Za taką uroczystość można niewątpliwie uznać Wielkanoc i związane z nią Triduum Paschalne. Jednak po ogłoszeniu stanu epidemicznego nie może dojść do sytuacji, w której duża liczba wiernych w tym samym czasie będzie prosiła o spowiedź, z powodu zakazu gromadzenia się ludzi.

Ponadto termin „poważna konieczność” charakteryzuje wspomniane już Motu proprio Misericordia Dei papieża Jana Pawła II.

${ }^{14}$ KPK 1983, kan. 961, par. 1, nr 2-3. 
Chodzi o sytuacje które obiektywnie są wyjątkowe, na przykład na terenach misyjnych czy w odizolowanych wspólnotach wiernych, do których kapłan może dotrzeć raz lub kilka razy w roku, kiedy pozwalają na to warunki. ${ }^{15}$ Wydaje się, że wymagana jest tutaj pewna stałość, niezmienność warunków życia wiernych z jaką najczęściej ma się do czynienia w krajach misyjnych czy w katolickich diasporach. Na miejscu nie ma kapłana, który przybywa do wiernych bardzo rzadko i na krótki czas, uniemożliwiający wyspowiadanie wszystkich proszących o sakrament. Polska nie jest diasporą, czy krajem misyjnym $\mathrm{z}$ brakiem spowiedników, a proboszczowie zazwyczaj na stałe przebywają w swoich parafiach, blisko wiernych. Jak na razie nie brakuje również dostatecznej liczby kapłanów.

Podczas epidemii koronowirusa wywołującego niebezpieczne dla życia zapalenie płuc w niektórych diecezjach polskich wprowadzono jednak absolucję generalną, powołując się na dyspozycję powyżej analizowanej normy. ${ }^{16}$ Wydaje się to błędem, gdyż sytuacja wymagała zastosowania punktu pierwszego tegoż kanonu. Stanowi on, że rozgrzeszenia wielu penitentów bez indywidualnej spowiedzi można również udzielić w przypadku gdy penitentom zagraża niebezpieczeństwo śmierci oraz brakuje czasu aby obecny kapłan lub kapłani wysłuchali spowiedzi poszczególnych penitentów. ${ }^{17}$ Tak jak zostało to ustalone we wcześniejszym punkcie tego opracowania, podczas obowiązywania stanu epidemicznego, a nawet kiedy nie obowiązuje, ale w rzeczywistości panuje w kraju czy w świecie poważna epidemia, można niewątpliwie twierdzić, iż wierni znaleźli się w niebezpieczeństwie śmierci - dalszym lub bliskim. Występuje również przesłanka braku czasu na spowiedź indywidualną, ponieważ dopuszcza się wtedy jedynie krótkie kontakty między ludźmi. Żeby się nie zarazić i nie przenosić choroby na bliźnich należy ograniczyć takie kontakty co do liczby osób i czasu bliskiego przebywania. Spowiedź

\footnotetext{
${ }^{15}$ Dok. cyt., s. 11.

${ }^{16}$ Por. https://kuria.gliwice.pl/2020/03/25/dekret-biskupa-gliwickiego-dnia-25-marca-2020-r [dostęp 2.04.2020]

${ }^{17}$ Kan. 961, par. 1, nr 1.
} 
indywidualna (a już szczególnie przedświąteczna) nie spełnia takich standardów. Stąd niektórzy biskupi wydali zakazy sprawowania sakramentu pokuty w formie zwyczajnej. ${ }^{18}$

Przypadek niebezpieczeństwa śmierci od poważnej konieczności różni się także tym, iż decyzję o zastosowaniu nadzwyczajnej formy sakramentu podejmuje osobiście spowiednik. Jak zauważa J. Krzywda, nie ma on obowiązku konsultowania się w danej sytuacji z kimkolwiek. ${ }^{19}$ Powinien jednak działać rozważnie, ponieważ sakramentów udziela się in persona Christi, co zobowiązuje do postępowania zgodnego z sumieniem..$^{20}$ Wymogu braku czasu na spowiedź indywidualną nie można interpretować kalkulując w sposób matematyczny. Trzeba brać pod uwagę możliwości związane z konkretną sytuacją. ${ }^{21}$ Absolucja generalna, w przeciwieństwie do indywidualnej, której udziela się jednemu penitentowi dotyczy jak stanowi norma kodeksowa, wielu penitentów, ${ }^{22}$ zatem co najmniej dwóch osób.

Ustawodawca nakłada na spowiednika udzielającego rozgrzeszenia zbiorowego w niebezpieczeństwie śmierci (o ile wystarcza na to czasu) obowiązek pouczenia penitentów, aby wzbudzili w sobie akt żalu za grzechy. ${ }^{23}$ Powinien również nałożyć na ich obowiązek podjęcia pewnego zadośćuczynienia. ${ }^{24}$ Ponadto norma kodeksowa stanowi wymóg do ważności rozgrzeszenia, którym jest odpowiednia dyspozycja penitenta oraz postanowienie, że we właściwym czasie wyzna przy spowiedzi indywidualnej grzechy ciężkie odpuszczone „zbiorowo”.

\footnotetext{
${ }^{18}$ Por. np. Wiktor Skworc, Zarządzenie arcybiskupa katowickiego odnośnie do sprawowania posługi duszpasterskiej i liturgicznej w najblizszych tygodniach, II, 2, 25.03.2020, w: https://archidiecezjakatowicka.pl/o-diecezji/aktualnosci/1192-sprawowanie-poslugi-duszpasterskiej-i-liturgicznej-w-najblizszym-czasie, [dostęp 2.04.2020].

${ }^{19}$ J. KRukowski, Sakrament pokuty, w: Komentarz do Kodeksu prawa kanonicznego, red. J. Krukowski, t. II/2, Poznań 2011, s. 145.

${ }^{20}$ M. Pastuszko, dz. cyt., s. 114.

${ }^{21}$ B.F. Pighin, Diritto sacramentale, Venezia 2006, s. 271.

${ }^{22}$ KPK 1983, kan. 961, par. 1.

${ }^{23}$ KPK 1983, kan. 962, par. 2.

${ }^{24}$ J. KRUKOwsKi, dz. cyt., s. 147.
} 
Aby być odpowiednio dysponowanym należy po przeprowadzeniu rachunku sumienia i wzbudzeniu żalu za grzechy zdecydować o zmianie swojego postępowania na lepsze. ${ }^{25}$ Penitent powinien również posiadać postanowienie naprawienia ewentualnych krzywd i skandali wywołanych przez swoje grzechy. Należy podkreślić, że spełnienie przedstawionych wymogów uzależnia ważność rozgrzeszenia zbiorowego, którego z tego powodu udziela się warunkowo. ${ }^{26} \mathrm{Co}$ do wymogu późniejszego wyznania grzechów ciężkich, wydaje się, że ustawodawcy chodzi tutaj o wyznaczenie za nie przez spowiednika adekwatnego zadośćuczynienia.

W praktyce rozgrzeszenia zbiorowego w niebezpieczeństwie śmierci udziela się stosując formułę rozgrzeszenia indywidualnego, zamieniając jedynie słowo „tobie” na „wam” (ja odpuszczam wam grzechy..). Kiedy nie ma bezpośredniego niebezpieczeństwa śmierci formułę wypowiada się w całości (Bóg i Ojciec miłosierdzia, który pojednał świat ze sobą....), natomiast przy bezpośrednim niebezpieczeństwie formułę skróconą (Ja odpuszczam wam grzechy...). ${ }^{27}$ Absolucja generalna może być zastosowana, kiedy kilka osób mając okazję spotkania się z kapłanem poprosi go o spowiedź, na przykład na sali szpitalnej, w domu opieki, przy okazji pogrzebu najbliższej osoby, udzielania wiatyku w mieszkaniu umierającego wiernego, itp.

Czy można udzielić sakramentalnego rozgrzeszenia na wzór absolucji generalnej pojedynczej osobie, gdy zarażona nie jest w stanie uczestniczyć w zwyczajnym obrzędzie i wyznać swoich grzechów? Wydaje się, że w takim przypadku, jeśli szeptem lub gestami poprosi o sakrament oraz ujawni swoją skruchę i żal za popełnione grzechy, spowiednik może stojąc w bezpiecznej odległości udzielić rozgrzeszenia.

\footnotetext{
${ }^{25}$ C. Krakowiak, Sakramenty uzdrowienia. Zagadnienia wybrane, Lublin 2016, s. $43-44$.

${ }^{26}$ E. Frank, I Sacramenti dell'Iniziazione, della Penitenza e dell'Unzione degli infermi, Citta del Vaticano 2012, s. 160.

${ }^{27}$ Obrzędy pokuty dostosowane do zwyczajów diecezji polskich, nr 64-76, Katowice 1981, s. 62-64.
} 
Z niebezpieczeństwem śmierci w odniesieniu do omawianego sakramentu łączy się jeszcze jedno ułatwienie. Z zasady do ważnego odpuszczania grzechów wymagane jest od szafarza posiadanie władzy święceń oraz upoważnienia do spowiadania. ${ }^{28}$ Zdarza się czasami, że niektórzy kapłani nie posiadają takiego upoważnienia na przykład $\mathrm{z}$ racji zaniedbania jego uzyskania, utraty, czy na skutek zaciągnięcia kary kanonicznej. Ustawodawca kościelny przewidując takie sytuacje zezwala na ważne i godziwe odpuszczanie grzechów podczas sakramentalnej spowiedzi, a także cenzur, jeśli penitent znajduje się w niebezpieczeństwie śmierci. Może tego dokonywać nawet przy obecności innego kapłana posiadającego wspomniane upoważnienie. ${ }^{29}$ Dotyczy to również cenzur zastrzeżonych Stolicy Apostolskiej. ${ }^{30}$ Warunkiem koniecznym jest tutaj posiadanie ważnych święceń kapłańskich, ponieważ żadna kara nie pozbawia władzy święceń, mogąc jedynie zakazać jej wykonywania. Dotyczy to nawet kapłanów, którzy utracili przynależność do stanu duchownego, bądź nie utrzymują pełnej jedności z Kościołem katolickim. ${ }^{31}$ Zatem ważnego rozgrzeszenia mogą w niebezpieczeństwie śmierci udzielać kapłani, którzy przeszli do innych Kościołów i Wspólnot chrześcijańskich (wcześniej będąc katolickimi) oraz przeniesieni ze stanu duchownego przed lub po zawarciu małżeństwa.

Penitent, który w niebezpieczeństwie śmierci otrzymał absolucję od cenzury, zobowiązany jest po ustaniu takiego zagrożenia w przeciągu miesiąca odnieść się do kompetentnego przełożonego lub uprawnionego kapłana po mandaty, pod groźbą nawrotu cenzury. Nie ma natomiast obowiązku rekursu, uwolniony od cenzury latae sententiae nieorzeczonej i niezastrzeżonej Stolicy Apostolskiej. ${ }^{32}$

\footnotetext{
${ }^{28}$ KPK 1983, kan. 966, par. 1.

29 Tamże, kan. 976.

${ }^{30}$ J. KRukowski, dz. cyt., s. 160.

${ }^{31}$ J. Syry jCzy K, Sankcje w Kościele. Część ogólna. Komentarz, Warszawa 2008, s. 307.

${ }^{32}$ Tamże, s. 308.
} 
W niebezpieczeństwie śmierci można także rozgrzeszyć wspólnika grzechu przeciwko szóstemu przykazaniu. ${ }^{33}$ Nikt nie jest sędzią we własnej sprawie, stąd takowe rozgrzeszenie w zwyczajnych okolicznościach byłoby nieważne, a ponadto spowiednik zaciągnął by ekskomunikę latae sententiae zarezerwowaną Stolicy Apostolskiej. ${ }^{34}$ Warto zauważyć, że powyżej analizowane normy dotyczące spowiednika rozgrzeszającego wspólnika w grzechu oraz penitenta w karach kościelnych odnoszą się nie tylko do wiernego umierającego, ale również zdrowego, jednak przystępującego do sakramentu pokuty w czasie epidemii choroby zakaźnej, powodującej pojawienie się „zwyczajnego” niebezpieczeństwa śmierci.

\section{Sakrament namaszczenia chorych}

Z problemem choroby, a już szczególnie epidemii łączy się szczególnie sakrament namaszczenia chorych. Został on bowiem ustanowiony przez Chrystusa z myślą o umocnieniu osób chorujących. Udziela się go z użyciem oleju poświęconego przez biskupa w Wielki Czwartek podczas Mszy św. krzyżma. Jednak kiedy na terytorium państwa czy nawet kontynentu panuje stan klęski spowodowany np. epidemią choroby zakaźnej, dochodzi czasami do sytuacji, w której prezbiter nie ma do dyspozycji takiego oleju. Ustawodawca kościelny udziela mu wtedy upoważnienia, aby podczas sprawowania sakramentu w razie konieczności osobiście poświecił olej. ${ }^{35}$ Jak zauważa B.W. Zubert prawodawca nie określa natury ani stopnia tej konieczności, wolno zatem sądzić, że szafarz osobiście ocenia konkretną sytuację mając na uwadze, że ma to być vera necessitatis, chociaż stanu konieczności nie można ograniczać jedynie do niebezpieczeństwa śmierci. ${ }^{36}$ Stan epidemiczny niewątpliwie stanowi taką konieczność.

\footnotetext{
${ }^{33}$ KPK 1983, kan. 977.

${ }^{34}$ E. Miragoli, Il sacramento della penitenza, w: Codice di diritto canonico commentario, Milano 2009, s. 804; D. Borek, Sextum Decalogi praeceptum w kanonicznym prawie karnym aktualnie obowiązującym, Tarnów 2015, s. 90-91.

${ }^{35}$ KPK 1983, kan. 999, pkt. 2.

${ }^{36}$ B.W. Zubert, Sakrament namaszczenia chorych, w: Komentarz do Kodeksu prawa kanonicznego, red. J. Krukowski, t. II/2, Poznań 2011, s. 188-189.
} 
Omawianego sakramentu można udzielić wiernemu, który po osiągnięciu używania rozumu znalazł się w niebezpieczeństwie na skutek choroby lub starości. ${ }^{37}$ Przyjmującemu nie musi grozić bezpośrednie niebezpieczeństwo śmierci. Ustawodawcy zależy jednak na wyeliminowaniu nadużyć, które występowały w przeszłości, kiedy namaszczenie rezerwowano dla osób in extremis, albo w późniejszym okresie (po Soborze Watykańskim II) czasami udzielano osobom w podeszłym wieku, jednak zupełnie zdrowym. Prawidłowo oceniając, chodzi o stan poważny, powodujący dotkliwe cierpienie, kryjący w sobie niebezpieczeństwo utraty życia. ${ }^{38}$ Jednak omawiane niebezpieczeństwo powinno być rzeczywiste, a nie tylko potencjalne, grożące każdej osobie w podeszłym wieku, które staje się rzeczywistym, kiedy taka osoba utraci nagle siły. ${ }^{39}$

Zatem ustawodawca nie ma tu na uwadze jakiegokolwiek niebezpieczeństwa spowodowanego chorobą albo starością. Niebezpieczna choroba skutkuje zazwyczaj mocnym pogorszeniem samopoczucia chorego. Również w podeszłym wieku dochodzi z czasem do poważnego pogorszenia samopoczucia, skłaniającego do interwencji lekarskiej. Takie pogorszenie łączy się również z niebezpiecznym zabiegiem chirurgicznym, stąd przed tego rodzaju operacją (przewidując późniejszy stan chorego), w praktyce duszpasterskiej także udziela się namaszczenia chorych. Ostatnia z opisywanych sytuacji posiada wiele analogii do takich, gdy osoba chora jest leczona w szpitalu, w podeszłym wieku przebywa w domu opieki, albo nawet w rodzinie, czyli w miejscach gdzie znalazły się inne osoby z personelu, pensjonariuszy, pacjentów lub członków rodziny, zarażone chorobą zakaźną podczas epidemii. Niebezpieczeństwo zarażenia się w grupie jest poważne, a jak wiadomo chorzy czy osłabieni starością są bardziej narażeni na choroby zakaźne. Można zatem przypuszczać, że wiele z nich zachoruje na rozprzestrzeniającą się chorobę i pogorszy się ich

\footnotetext{
${ }^{37}$ KPK 1983, kan. 1004, par. 1.

${ }^{38}$ B.W. Zubert, dz. cyt., s. 200.

${ }^{39}$ Z. JAnCZEwski, Przyjmujacy sakrament namaszczenia chorych, Prawo Kanoniczne 55(2012) nr 4, s. 46.
} 
samopoczucie, może się też w niedługim czasie pojawić bezpośrednie niebezpieczeństwo utraty życia. W takiej sytuacji nie będzie nadużyciem udzielenie osobom zagrożonym omawianego sakramentu.

Rozprzestrzenianie się choroby zakaźnej ułatwia niekontrolowane kontaktowanie się z wieloma osobami. Takim kontaktem będzie udzielanie sakramentu większej liczbie wiernych w formie indywidualnej, czyli przechodząc od jednaj do drugiej i odmawiają przy każdej wszystkie modlitwy przewidziane przez księgę liturgiczną. W sytuacji epidemii po raz kolejny z pomocą przychodzi norma kanoniczna. Stanowi ona, iż możliwe jest wspólne sprawowanie namaszczenia chorych dla wielu osób równocześnie, którzy są odpowiednio przygotowani i właściwie dysponowani. ${ }^{40}$ Stosowana jest między innymi w szpitalach, hospicjach, lub domach pomocy osobom starszym, za zezwoleniem ordynariusza miejsca. ${ }^{41}$ Zezwolenie jest wydawane dla poszczególnych przypadków, o ile nie zostało zawarte we wcześniej promulgowanych przez ordynariusza przepisach, dotyczących wspólnego sprawowania omawianego sakramentu. ${ }^{42}$

W praktyce, przy zagrożeniu epidemicznym szafarz sakramentu powinien najpierw krótko przygotować wiernych do jego przyjęcia (a także do sakramentu pokuty i pojednania udzielonego przed namaszczeniem), udzielić absolucji generalnej, odmówić modlitwy przewidziane podczas celebracji namaszczenia, po czym namaścić indywidualnie osoby na sali. Należałoby to powtarzać w każdym pomieszczeniu w którym znajdują się starsi lub chorzy.

W przypadku konieczności szafarz może zastosować obrzęd skrócony. Polega on na namaszczeniu czoła lub innej części ciała i wypowiedzenie formuły sakramentalnej. ${ }^{43}$ Kanon, jak zauważa M. Pastuszko, nie zawęża takich przypadków jedynie do bliskiego

\footnotetext{
${ }^{40}$ KPK 1983, kan. 1002.

${ }^{41}$ Rituale Romanum ex decreto Sacrosancti Oecumenii Concilii Vaticani II instauratum, Auctoritate Pauli PP. VI promulgatum, Ordo Unctionis Infirmorum eorumque Pastoralis Curae, nr 17, Typis Polyglottis Vatikans 1972, s. 83-84.

${ }^{42}$ Z. JANCZEWsKi, dz. cyt., s. 48.

${ }^{43}$ KPK 1983, kan. 1000, par. 2.
} 
niebezpieczeństwa śmierci, nie zawierając przyczyny powodującej stan konieczności. Stąd stan konieczności może dotyczyć nie tylko przyjmującego sakrament, ale również szafarza. ${ }^{44}$ Takim stanem konieczności jest niewątpliwie zagrożenie epidemiczne, podczas którego trzeba ograniczać wszelkie kontakty fizyczne z osobą chorą, lub potencjalnie zarażoną. Namaszczanie dowolnej, możliwej części ciała jest wtedy nie tylko uzasadnione, ale nawet konieczne. Bo przykładowo podczas epidemii koronowirusa powodującego ostre zapalenie płuc, niektórzy chorzy po podłączeniu do respiratora mają zakryte czoło a nawet całą głowę specjalna maską. W sytuacji bliskiego niebezpieczeństwa śmierci, a także agonii szafarz po krótkiej modlitwie wstępnej namaszcza wypowiadając jedynie formułę sakramentalną.

Namaszczenie powinno się dokonywać ręką szafarza, chyba że poważna racja zaleca zastosowanie narzędzia. ${ }^{45}$ Zatem w zwykłych okolicznościach czyni się to przez bezpośredni kontakt fizyczny ręki kapłana $z$ ciałem osoby namaszczanej. Poważna racja uzasadnia jednakże użycie narzędzia. Stanowi ją niebezpieczeństwo zarażenia się szafarza. W takim przypadku powinien on zastosować środki ostrożności, jakie przeciw infekcji stosują lekarze czy pielęgniarki. ${ }^{46}$ Dla uniknięcia kontaktu z raną lub ciałem pacjenta w służbie zdrowia używa się specjalnych narzędzi, przypominających duże nożyczki, noszących nazwę pean, pensety chirurgicznej, itd. Narzędziem takim należy przytrzymać kawałek waty zamoczonej w poświęconym oleju, a następnie namaścić ciało wiernego. Po użyciu wata powinna być niezwłocznie spalona. Nie wolno używać tej samej waty do namaszczenia kolejnej osoby, bo grozi to ewentualnym przeniesieniem choroby zakaźnej, ponieważ niektóre z nich przenoszą się w wydzielinach, na przykład w ludzkim pocie.

Jakim osobom znajdującym się w poważnym niebezpieczeństwie z powodu epidemii należy udzielić lub odmówić namaszczenia

\footnotetext{
${ }^{44}$ M. PAstuszko, Sakrament namaszczenia chorych, w: Duszpasterstwo w świetle nowego Kodeksu prawa kanoniczego, red. J. Syryjczyk, Warszawa 1985, s. 168.

${ }^{45}$ KPK 1983, kan. 1000, par. 2.

${ }^{46}$ B.W. Zubert, dz. cyt., s. 191.
} 
chorych? Zakaz udzielania dotyczy nieprzytomnych, którzy przed utratą przytomności przynajmniej pośrednio nie prosili o namaszczenie. Wymaga się bowiem, aby posiadający używanie rozumu wyraził wolę otrzymania sakramentu. ${ }^{47}$ Prośba uzewnętrznia wewnętrzną intencję sakramentalną, konieczną do ważności przyjęcia sakramentu. W przypadku nieprzytomnego wystarcza intencja habitualna, raz wyrażona i później nie odwołana. W przypadku osób religijnych można przypuszczać, że przed utratą przytomności posiadali wolę zwrócenia się o sakrament w ekstremalnych sytuacjach życiowych. ${ }^{48}$ Jeśli ktoś wyraził taką wolę wcześniej, w obecności innego chorego, swojego krewnego, czy personelu medycznego, a potem stracił przytomność, namaszczenia trzeba udzielić. Jeśli natomiast o osobie nic nie wiadomo, czy jest osobą wierzącą, katolikiem, a nawet czy została ochrzczona, nie wolno sprawować sakramentu.

Zakaz dotyczy również wiernych uparcie trwających w jawnym grzechu ciężkim. ${ }^{49} \mathrm{~W}$ praktyce niezwykle trudnym jest stwierdzenie uporu, ponieważ osoba odczuwająca strach przed śmiercią zazwyczaj gotowa jest przyrzec, że zerwie ze wszystkim, czego się od niej wymaga. Stąd też wspomniana trudność. Należy się zatem posiłkować oznakami pokuty z jej strony, a każdy przypadek traktować indywidualnie. ${ }^{50}$ Niektórym publicznym grzesznikom, np. żyjącym w związkach niesakramentalnych z powodu przeszkody węzła małżeńskiego wiążącego $\mathrm{z}$ osobą, z którą wcześniej zawarły sakramentalne małżeństwo, regularnie uczestniczących we Mszach św. i innych formach życia Kościoła, można w niebezpieczeństwie śmierci udzielić omawianego sakramentu, nawet jeżeli są nieprzytomne. Zachodzi tutaj domniemanie, że posiadają intencję przyjęcia namaszczenia, ponieważ starały się po części żyć po chrześcijańsku. ${ }^{51}$ Stosuje się tu

\footnotetext{
${ }^{47}$ KPK 1983, kan. 843, par. 1.

${ }^{48}$ Z. JANCZEWSKi, dz. cyt., s. 52.

${ }^{49}$ KPK 1983, kan. 1007.

${ }^{50}$ B.W. Zubert, dz. cyt., s. 204-205.

${ }^{51}$ M. Pastuszko, Sakrament namaszczenia..., s. 194.
} 
bowiem zasadę, według której zbawienie człowieka stanowi najważniejszą rację prawną dla udzielania sakramentu.

\section{Zakończenie}

Jezus, lekarz dusz i ciał ludzkich, odpuszczający grzechy i uzdrawiający z różnych chorób ludzi pragnie, żeby Kościół mocą Ducha św. kontynuował Jego dzieło uzdrawiania i zbawiania, obejmujące obok duszy także ludzkie ciało. Jest to zasadniczy cel dwóch sakramentów uzdrowienia - pokuty i namaszczenia chorych.

Dnia 14 marca 2020 roku został wprowadzony w Polsce stan zagrożenia epidemicznego. Było to związane z rozprzestrzeniającym się w świecie i Polsce niezwykle niebezpiecznym dla zdrowia i życia wirusem SARS-CoV2. Najbardziej skuteczną metodą pomagającą opanować epidemię jest ograniczenie kontaktów międzyludzkich. Stanowi to jednak problem w przypadku sprawowania sakramentów, w tym również pokuty i namaszczenia chorych, dzięki którym, osoby zarażone, a także żyjący w potencjalnym zagrożeniu zarażeniem otrzymują pojednanie z Bogiem i Kościołem oraz łaski duchowe, pomagające w walce $z$ chorobą.

Prawo kanoniczne nie zna terminu „stan epidemiczny”, stosuje natomiast inny - „niebezpieczeństwo śmierci”. Przez niebezpieczeństwo śmierci rozumie się stan, kiedy utrata życia ludzkiego jest prawdopodobna, ale nie jest równocześnie wykluczone przeżycie człowieka. Czy w przypadku stanu epidemicznego można mówić o znajdowaniu się wiernego w niebezpieczeństwie śmierci? Co do tego nie ma wątpliwości. Epidemia choroby zakaźnej stwarza sytuację, w której prawie każdy człowiek może się taką chorobą zakazić, nawet stosując się do szczególnych zasad higieny. Natomiast fakt zarażenia naraża go na realne niebezpieczeństwo utraty życia. Znajduje się zatem, jak to zostało wykazane w powyższym artykule, w stanie kanonicznie rozumianego niebezpieczeństwa śmierci.

W przypadku gdy wiernym zagraża niebezpieczeństwo śmierci oraz brakuje czasu aby obecny kapłan lub kapłani wysłuchali spowiedzi poszczególnych penitentów, można udzielić równoczesnego rozgrzeszenia wielu penitentom bez przystąpienia przez nich do 
spowiedzi indywidualnej. Podczas obowiązywania stanu epidemicznego, a nawet kiedy nie obowiązuje, ale w rzeczywistości panuje w kraju czy w świecie poważna zakaźna epidemia, zakłada się że wierni znaleźli się w niebezpieczeństwie śmierci - dalszym lub bliskim. Występuje równocześnie przesłanka braku czasu na spowiedź indywidualną, ponieważ dopuszcza się wtedy jedynie krótkie kontakty między ludźmi. Aby nie doszło do zarażenia i przenoszenia choroby na bliźnich, należy ograniczać takie kontakty co do liczby osób i czasu bliskiego przebywania. Spowiedź indywidualna (a już szczególnie przedświąteczna) nie spełnia takich standardów. Absolucja generalna może być zastosowana, kiedy kilka osób mając okazję spotkania się z kapłanem poprosi go o spowiedź, na przykład na sali szpitalnej, w domu opieki, przy okazji pogrzebu najbliższej osoby, udzielania wiatyku w mieszkaniu umierającego wiernego, itp. Ponadto możliwe jest udzielenie sakramentalnego rozgrzeszenia na wzór absolucji generalnej pojedynczej osobie, gdy zarażona nie jest w stanie uczestniczyć w zwyczajnym obrzędzie i wyznać swoich grzechów.

Ustawodawca kościelny przewidując tak trudne sytuacje, zezwala nie tylko na ważne i godziwe odpuszczanie grzechów, ale także cenzur, jeśli tylko penitent znajduje się w niebezpieczeństwie śmierci. Może tego dokonywać nawet kapłan nie posiadający upoważnienia do spowiadania, przy obecności innego, który takowe posiada. Dotyczy to między innymi cenzur zastrzeżonych Stolicy Apostolskiej i odnosi się nawet do kapłanów, którzy utracili przynależność do stanu duchownego, bądź nie utrzymują pełnej jedności z Kościołem katolickim. W niebezpieczeństwie śmierci można także rozgrzeszyć wspólnika grzechu przeciwko szóstemu przykazaniu.

Kiedy na terytorium państwa czy nawet kontynentu panuje stan klęski spowodowany np. epidemią choroby zakaźnej, dochodzi czasami do sytuacji, w której prezbiter nie ma do dyspozycji oleju wymaganego do ważnego sprawowania sakramentu chorych. Ustawodawca kościelny udziela mu wtedy upoważnienia, aby podczas celebrowania sakramentu w razie konieczności osobiście poświęcił olej.

W sytuacji gdy chory jest leczony w szpitalu, w podeszłym wieku przebywa $\mathrm{w}$ domu opieki, albo nawet $\mathrm{w}$ rodzinie, a zatem $\mathrm{w}$ miejscach 
gdzie nieszczęśliwie znalazły się inne osoby z personelu, pensjonariuszy, pacjentów lub członków rodziny, zarażone chorobą zakaźną podczas epidemii, niebezpieczeństwo zarażenia się w większej grupie jest jeszcze poważniejsze. Chorzy czy osłabieni starością są bardziej narażeni na choroby zakaźne. Można zatem domniemywać, że wielu z nich zachoruje na rozprzestrzeniającą się chorobę i pogorszy się ich samopoczucie, a w niedługim czasie pojawi się bezpośrednie niebezpieczeństwo utraty życia. W takiej sytuacji nie będzie nadużyciem udzielenie osobom zagrożonym omawianego sakramentu.

Ustawodawca kościelny przewiduje wspólne sprawowanie namaszczenia chorych dla wielu osób równocześnie, którzy są odpowiednio przygotowani i właściwie dysponowani. Może się to odbywać między innymi w szpitalach, hospicjach, lub domach pomocy osobom starszym, za zezwoleniem ordynariusza miejsca. W przypadku konieczności szafarz sprawuje sakrament według obrzędu skróconego. Polega on jedynie na namaszczeniu czoła lub innej części ciała i wypowiedzenie formuły sakramentalnej.

Jeżeli pojawia się niebezpieczeństwo zarażenia szafarza, powinien on zastosować środki ostrożności, jakie przeciw infekcji używają lekarze czy pielęgniarki. Dla uniknięcia kontaktu z raną lub ciałem pacjenta w służba zdrowia posługuje się się specjalnymi narzędziami. Do namaszczenia chorych można wtedy posłużyć się na przykład pensetą w której trzyma się watę nasączoną świętym olejem.

Reasumując można stwierdzić, że ustawodawca kościelny przewidział niejako sytuacje, w których podczas epidemii choroby zakaźnej nie można w sposób zwyczajny celebrować sprawowanie omawianych sakramentów i wprowadził do Kodeksu prawa kanonicznego normy nadzwyczajne, ułatwiające udzielanie i przyjmowanie pokuty oraz namaszczenia chorych. 


\section{The celebration of the sacraments penance and anointing of the sick during the state of emergency epidemic according to canon law}

At the beginning of 2020 year in the world the virus outbreak began. An epidemic emergency has been introduced in Poland. The best method to stop epidemic is to reduce people-to-people contacts. Such actions create problems for the administration of the sacraments. This article is about celebration of the sacraments penance and anointing of the sick according to canon law, during the danger of an ongoing epidemic.

SŁOWA KLUCZOWE: prawo kanoniczne; epidemia; sakrament pokuty; sakrament namaszczenia chorych; stan epidemiczny; niebezpieczeństwo śmierci; celebrowanie sakramentów

KEYwORDs: Canon law; epidemic; sacrament penance; sacrament anointing of the sick; epidemic emergency; danger of death; celebration of the sacraments

\section{Nota o AUTORze}

Ks. PROF. DR HAB. ZBIGNIEW JANCZEWSKI - pracownik naukowo-dydaktyczny na Wydziale Prawa Kanonicznego Uniwersytetu Kardynała Stefana Wyszyńskiego w Warszawie, kierownik Katedry Prawa o Posłudze Nauczania i Uświęcania. Członek Rady Doskonałości Naukowej. 